\title{
Effect of Halogen Doping on Optical Properties for ZnO Thin Film Prepared by Thermal Oxidation
}

\author{
Wael ABDULLAH \\ Department of Basic sciences, Faculty of Mechanical and Electrical Engineering, \\ University of Al-Baath, Homs, Syria.
}

E-mail address: wabdullah75@yahoo.co.uk

Keywords: $\mathrm{ZnO}$; Thermal Oxidation; Thin film; optical properties, halogens $(\mathrm{Cl}, \mathrm{Br}, \mathrm{I})$

\begin{abstract}
Undoped and halogen-doped zinc oxide thin films are prepared by the thermal oxidation process. Zinc acetate dihydrate, ethanol, and Diethanolamine are used as precursor, solvent, and stabilizer, respectively. In the case of $\mathrm{ZnO}$ :Hal. dopant Ammonium chloride $\mathrm{NH}_{4} \mathrm{Cl}$ $99 \%$, Benzene Bromide $\mathrm{C}_{6} \mathrm{H}_{5} \mathrm{Br}$, or Benzene Iodide $\mathrm{C}_{6} \mathrm{H}_{5} \mathrm{I}$ for making dopant $\mathrm{ZnO}$ thin film with $\mathrm{Cl}, \mathrm{Br}$, I respectively is added to the precursor solution with an atomic percentage equal to $2-10 . \%$ hal. The transparent solution sprayed onto glass substrates, and are transformed into $\mathrm{ZnO}$ upon annealing at $500^{\circ} \mathrm{C}$. XRD spectra of $\mathrm{ZnO}$ thin films, and optical properties of them as a function of halogen content have been investigated using U.V spectroscopy ( transmittance, refractive index, extinction coefficient and energy band gap ) for undoped and halogen-doped zinc oxide thin films.
\end{abstract}

\section{INTRODUCTION}

$\mathrm{ZnO}$ thin film is one of the II-VI compound semiconductors and is composed of hexagonal wurtzite crystal structure. $\mathrm{ZnO}$ thin film presents investigating optical, and electrical properties which meet extent applications in the fields of electronics, optoelectronics and sensors. $\mathrm{ZnO}$ thin film is applied to the transparent conductive film and the solar cell window because of the high optical transmittance in the visible region [1-5]. ZnO can be a $n$-type and a $p$-type semiconductor determined by the dopant nature [6,7]. $n$-Type doping of $\mathrm{ZnO}$ is relatively easy compared to $p$-type doping [7] and reproducible $p$-type conductivity, However, $p$-type doping in ZnO may be possible by substituting either group-I elements ( $\mathrm{Li}, \mathrm{Na}, \mathrm{K}$, etc.) for $\mathrm{Zn}$-atoms or group-V elements $(\mathrm{N}, \mathrm{P}$, $\mathrm{As}, \mathrm{Sb}$, etc.) for O-atoms [6-9], For $n$-type [6,7,9-12], doping with group-III elements (B, Al, Ga, In), as substitutional elements for $\mathrm{Zn}$, has been attempted by many groups, resulting in high-quality, optically transparent, and highly conductive $\mathrm{ZnO}$ films as this substitution of divalent $\mathrm{Zn}^{2+}$ by a trivalent ion generates an excessive free electron. Especially, Al-doped $\mathrm{ZnO}$ (AZO) thin films have attracted a considerable amount of interest due to their good electrical conductivity with reasonably low optical loss [13].

On the other hand, $n$-type semiconductors may also be synthesized by substituting O-atoms by group-VII elements (F, Cl, Br, I) [7]. The $\mathrm{ZnO}$ thin film is prepared using various methods such as spray pyrolysis, sputtering, sol-gel spin coating, pulsed laser deposition (PLD), chemical vapor deposition (CVD) [14-17]. In spite of few studies regarding to Thermal Oxidation method, the Oxidation method has some merits, such as the easy control of chemical components, and fabrication of thin film at a low cost to investigate structure and optical properties of $\mathrm{ZnO}$ thin films. Optical properties of thin films are very important for the designing of solar cells and optoelectronic devices. In particular, the information about optical constants such as refractive index $(\mathrm{n})$, the extinction coefficient $(\mathrm{k})$ and energy band gap $\left(\mathrm{E}_{\mathrm{g}}\right)$ play a vital role in the designing of optoelectronic devices. They are extensively used for characterization of composition of material over a wide range of wavelength in optic devices [18]. 


\section{EXPERIMENTAL}

\subsection{Experimental procedure [19-21]}

To synthesize the $\mathrm{ZnO}$ solution, $10.95 \mathrm{gr}$ of zinc acetate dehydrate $\left(\mathrm{Zn}\left(\mathrm{CH}_{3} \mathrm{COO}\right)_{2} \cdot 2 \mathrm{H}_{2} \mathrm{O}\right)$ from Prolabo lot $(* 687 \mathrm{G}) \mathrm{M}=219.5 \mathrm{gr} / \mathrm{mol}$ was first dissolved in an ethanol solvent (ethanol absolut puriss.p.a.) from Sigma-aldrich lot (82499) in a $100 \mathrm{ml}$ flask and was stirred for $15 \mathrm{~min}$ at room temperature to yield a milky solution then $2.5 \mathrm{ml}$ of diethanolamine (DEA)from Merck was dropped carefully to the solution as a stabilizer, the complex solution was stirred for other 15 minutes until get a transparent, homogenous, and stable sol. We used ethanol, cause of a low boiling point and non-toxicity solvent.

Un-doped $\mathrm{ZnO}$ thin films were coated onto pre-cleaned glass substrates Soda-lime $5 \times 2 \mathrm{~cm}^{2}$ by spray the solution on it, each coated film was heated at $500{ }^{\circ} \mathrm{C}$ for 50 minutes then annealing to room temperature.

For dopant $\mathrm{ZnO}$ thin film we add a fixed amount of dopant Ammonium chloride Extra pure $\mathrm{NH}_{4} \mathrm{Cl}$ 99\% Labo Chemie India, Benzene Bromide $\mathrm{C}_{6} \mathrm{H}_{5} \mathrm{Br}$ from Merck 99\% $\mathrm{M}=157.02$ gr/mol, Benzene Iodide $\mathrm{C}_{6} \mathrm{H}_{5} \mathrm{I}$ from $\mathrm{BDH} 98 \% \mathrm{M}=204.01 \mathrm{gr} / \mathrm{mol}$ for making dopant $\mathrm{ZnO}$ thin film for $\mathrm{Cl}$, $\mathrm{Br}$, I respectively.

Doped $\mathrm{ZnO}$ thin were coated onto pre-cleaned glass substrates Soda-lime $5 \times 2 \mathrm{~cm}^{2}$ by spray the solution on it, each coated film was heated at $500{ }^{\circ} \mathrm{C}$ for 50 minutes then annealing to room temperature.

A flow chart .1 summarize the experimental procedure for pure and dopant $\mathrm{ZnO}$ thin film flowchart .1 The experimental procedure for pure and dopant $\mathrm{ZnO}$ thin film 


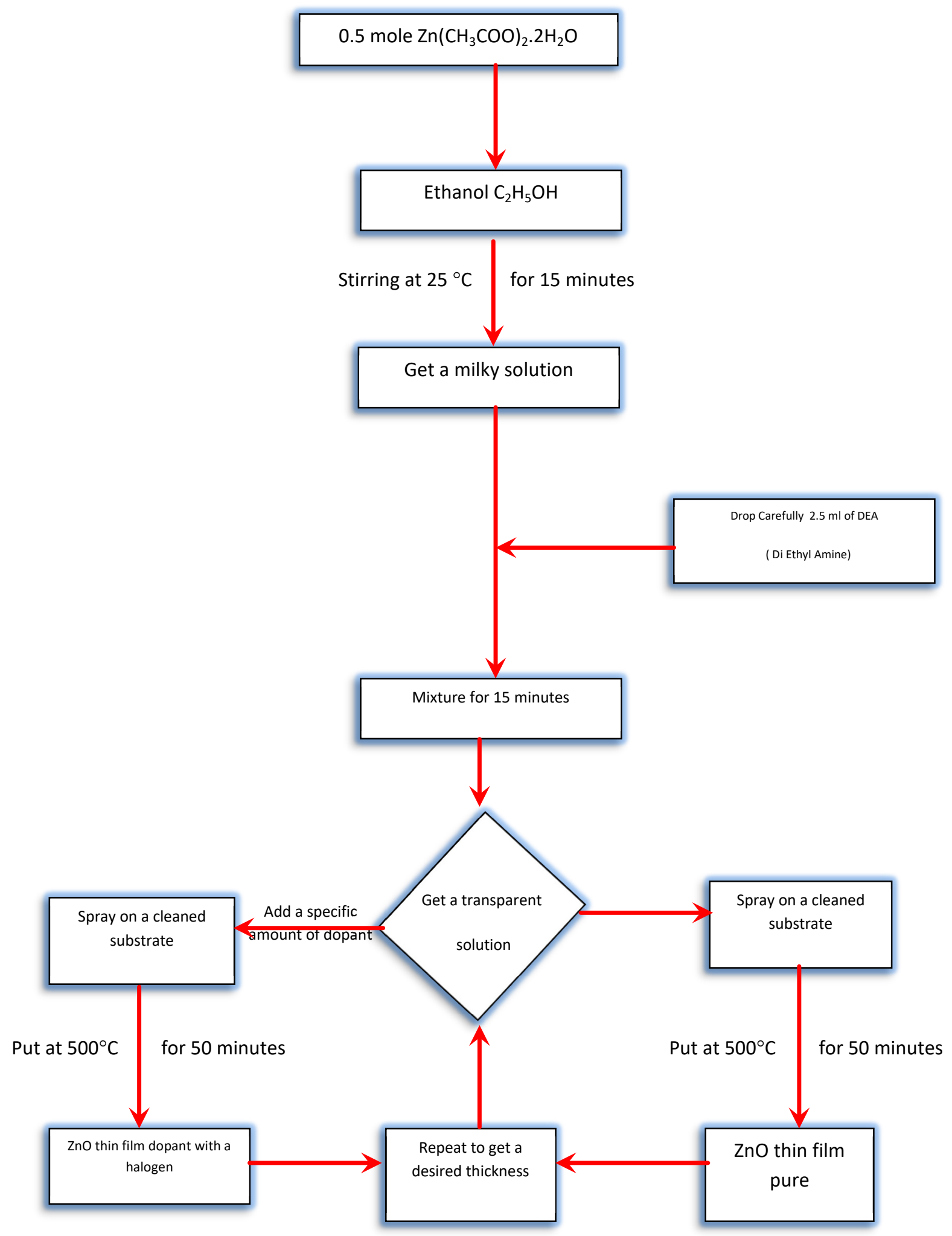

\section{RESULTS AND DISCUSSION :}

\subsection{Crystalline characterization by XRD measurements}

Philips analytical X-Ray Diffractometer type PW1840 at ALBAATH University was used with tube anode copper $\mathrm{Cu}$ at wavelength alpha $1,54 \mathrm{~A}^{\circ}$ from $2 \theta \quad 30-70^{\circ}$, figure 1 displays the XRD spectrum of $\mathrm{ZnO}$ pure thin films. Three lines (100) at $2 \theta=31.77^{\circ},(002)$ at $2 \theta=34.4^{\circ}$, and (101) at $2 \theta=$ $36.25^{\circ}$ are pointed, they will be considered for structural characterization of $\mathrm{ZnO}$. 


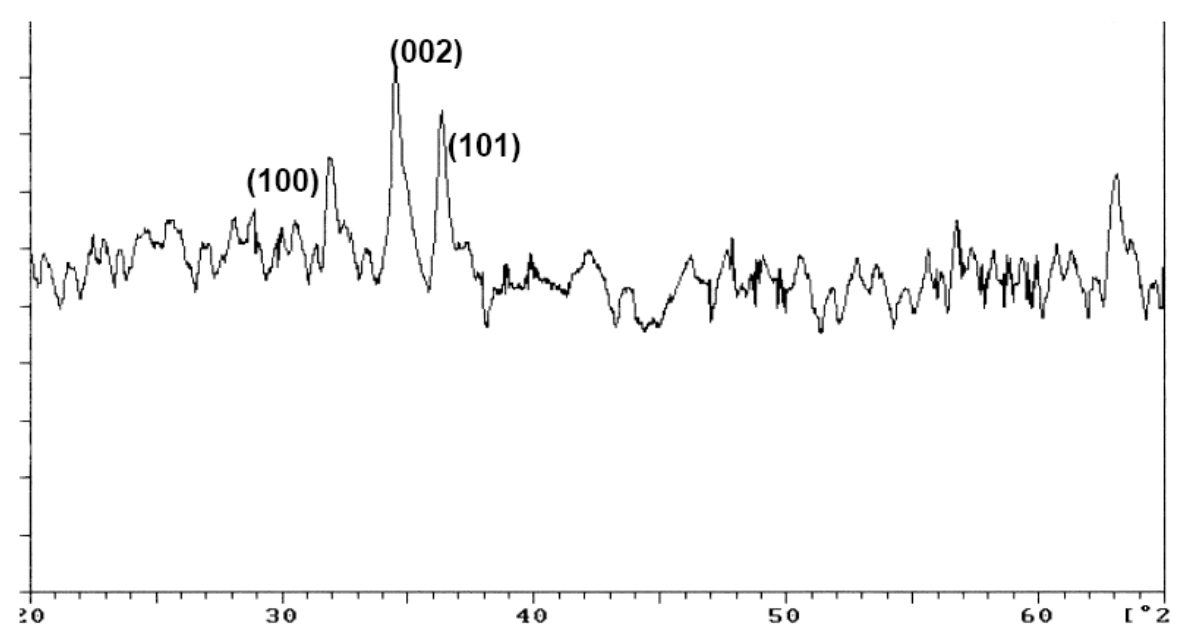

Figure 1: ZnO Pure thin film XRD Spectrum.[21,22]

We measured the XRD spectra for ZnO: Halogen with different Hal. ratio from $2 \%$ to $10 \%$ and found the following results represented in figure 2 .
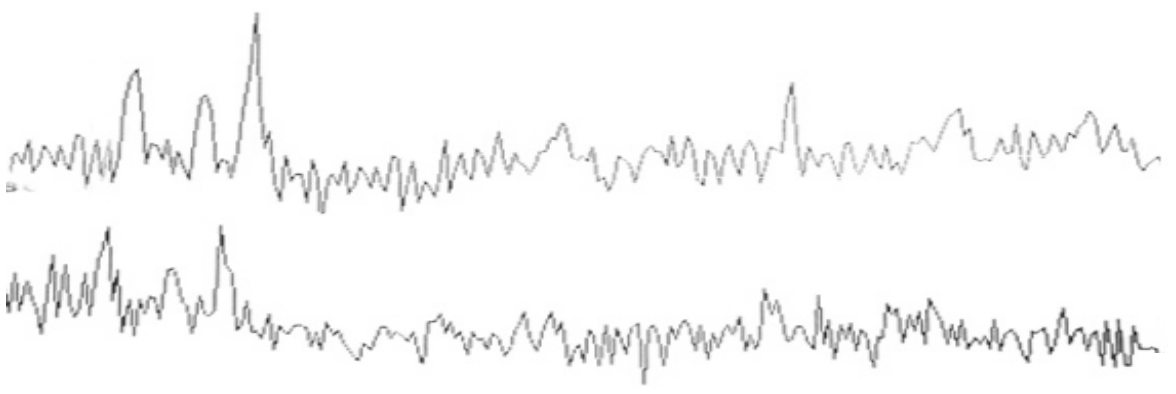

$\mathrm{ZnO}: \mathrm{Cl} 2 \%$

\section{$\mathrm{ZnO}: \mathrm{Cl} 6 \%$}
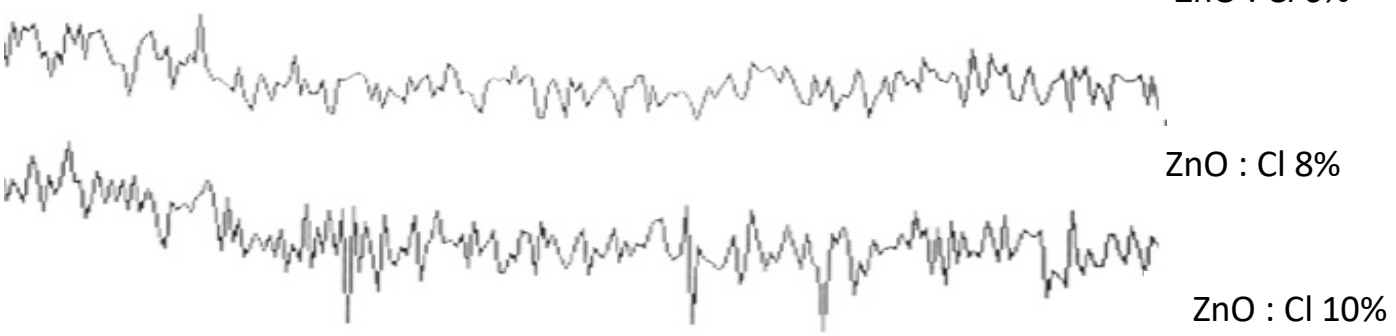

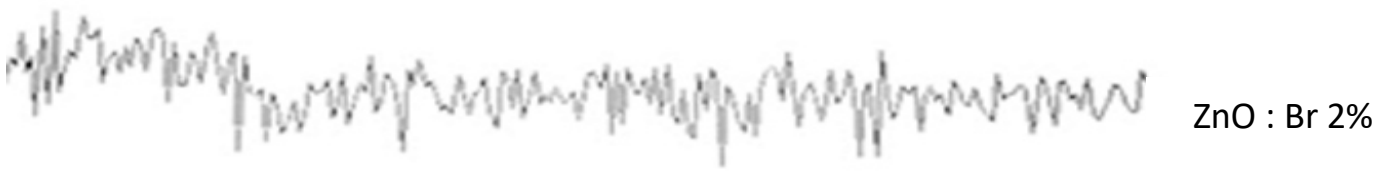

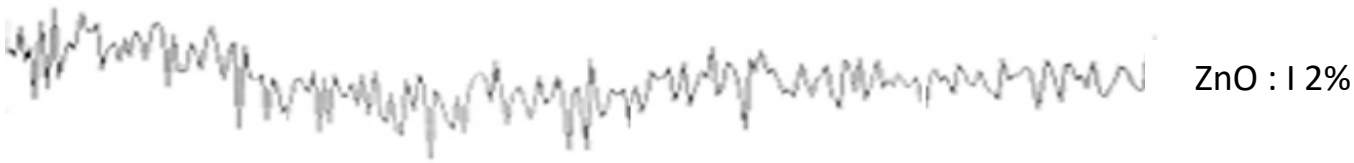

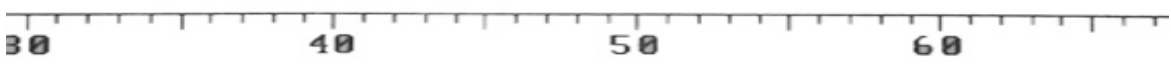

Figure 2: XRD Spectrums for $\mathrm{ZnO}$ : Hal.

A significant evolution of the resolutions of $\mathrm{ZnO}$ (100), (002) and (101) characteristic lines is obtained. The increase of $\mathrm{Cl}$ concentration in the starting material for the $\mathrm{ZnO}$ preparing process, leads to an amorphous stage of the films at $10 \%$ ratio, while we get an amorphous stage directly when we use $\mathrm{Br}$ or I as a dopant agent, and we think it refers to the atom size cause the atom size of $\mathrm{Cl}$ is near the same of oxygen while the atom size for $\mathrm{Br}$ or I is bigger and leads to get more defects in the crystal orientation of $\mathrm{ZnO}$ 


\subsection{Optical properties}

\subsubsection{Transmittance:}

\subsubsection{Transmittance for each halogen depends on dopant ratios:}

U.V Spectroscopy has Model V-570 and Serial No. C02 96774 at ALBAATH University was used to measure the transmittance of these thin films by using these parameters:

Band width $2.0 \mathrm{~nm}$, Measurement range 1100 - $400 \mathrm{~nm}$, Data pitch 2nm, Scanning speed 400 $\mathrm{nm} / \mathrm{min}$, Figure 3 displays the measured transmittance of the $\mathrm{ZnO}$ pure and $\mathrm{ZnO}: \mathrm{Hal}$. films in the rage $400 \mathrm{~nm}$ to $1100 \mathrm{~nm}$ for $2-10 \%$ ratios of Halogen dopants
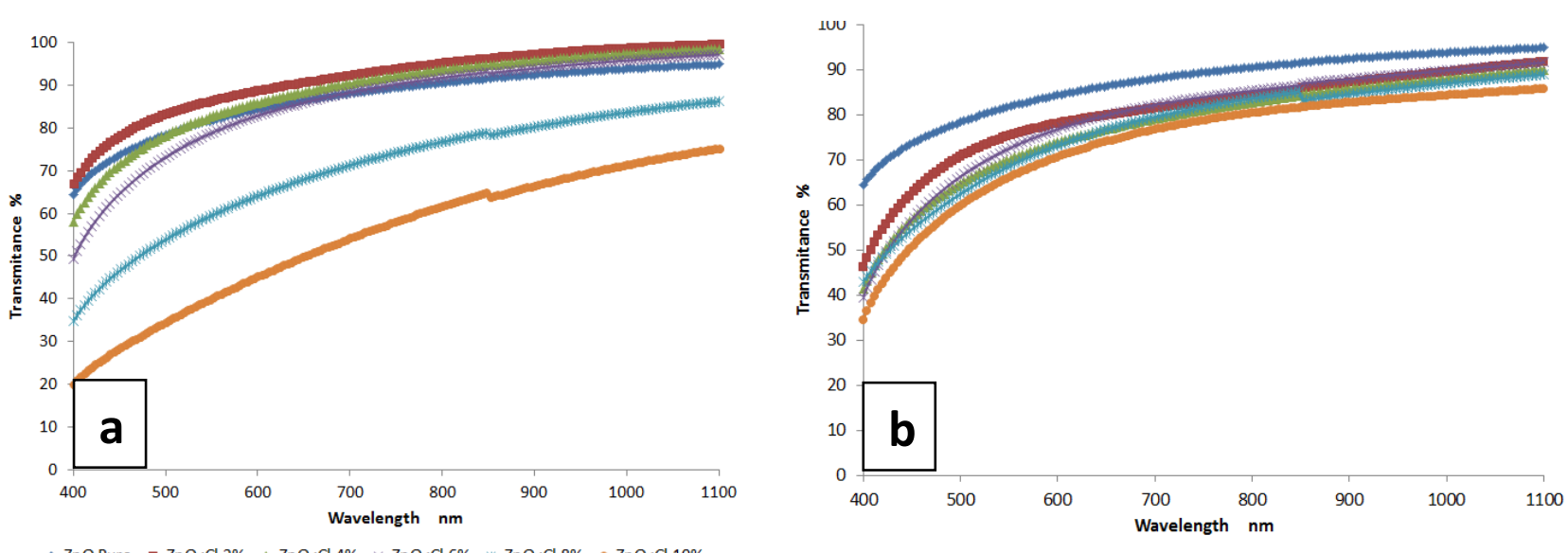

$\rightarrow-\mathrm{ZnO}$ Pure $\rightarrow-\mathrm{ZnO} 2 \% \mathrm{Br} \rightarrow-\mathrm{ZnO} 4 \% \mathrm{Br} * \mathrm{ZnO} 6 \% \mathrm{Br} * \mathrm{ZnO} 8 \% \mathrm{Br} \rightarrow-\mathrm{ZnO} 10 \% \mathrm{Br}$

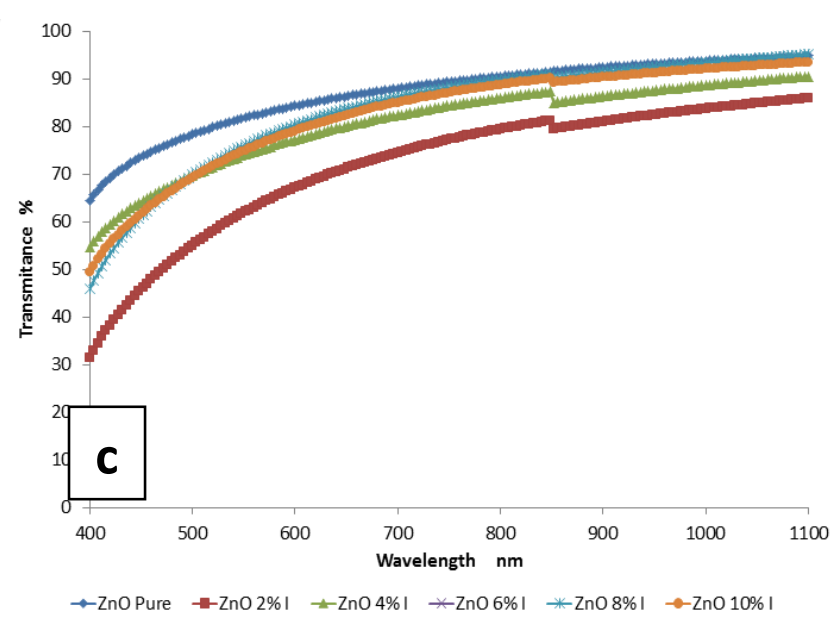

Figure 3: $\mathrm{ZnO}$ and $\mathrm{ZnO}: \mathrm{Hal}$. for 2-10\% ratios of Halogen dopants thin films transmittance spectroscopy a) $\mathrm{ZnO}: \mathrm{Cl}$ for $2-10 \%$ ratios, b) $\mathrm{ZnO}: \mathrm{Br}$ for $2-10 \%$ ratios, c) $\mathrm{ZnO}$ : I for $2-10 \%$ ratios

\subsubsection{Transmittance for halogens at fixed dopant ratios:}

Figure 4 displays the measured transmittance of the $\mathrm{ZnO}$ pure and $\mathrm{ZnO}: \mathrm{Hal}$. films in the rage 400 $\mathrm{nm}$ to $1100 \mathrm{~nm}$ at fixed dopant ratios from $2 \%-10 \%$ 


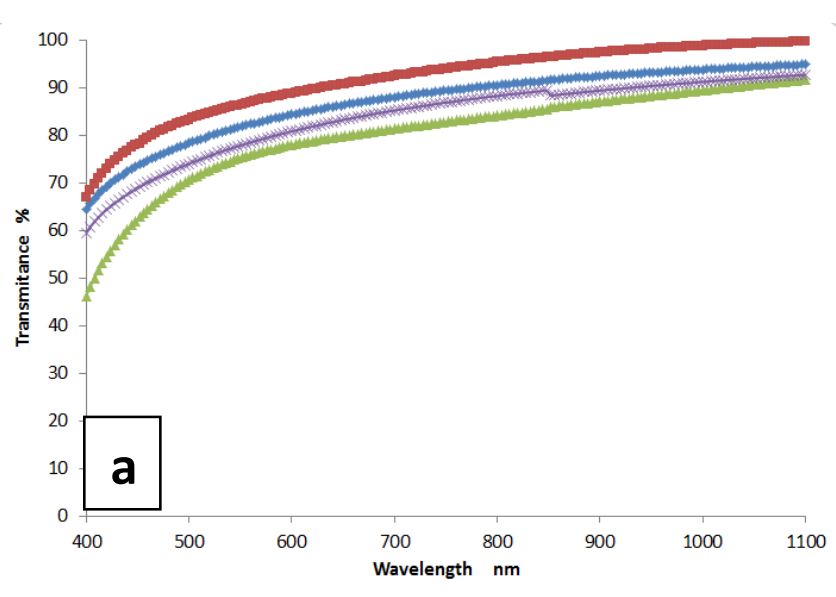

$\rightarrow-\mathrm{ZnO}$ Pure $\quad \rightarrow-\mathrm{ZnO}: \mathrm{Cl} 2 \% \quad \rightarrow-\mathrm{ZnO}: \mathrm{Br} 2 \% \quad \div \mathrm{ZnO}: 12 \%$

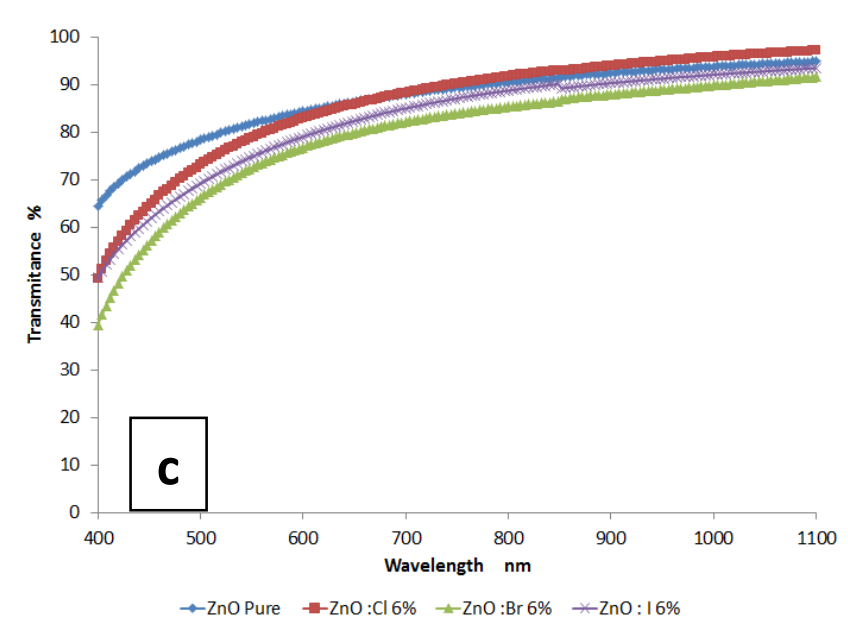

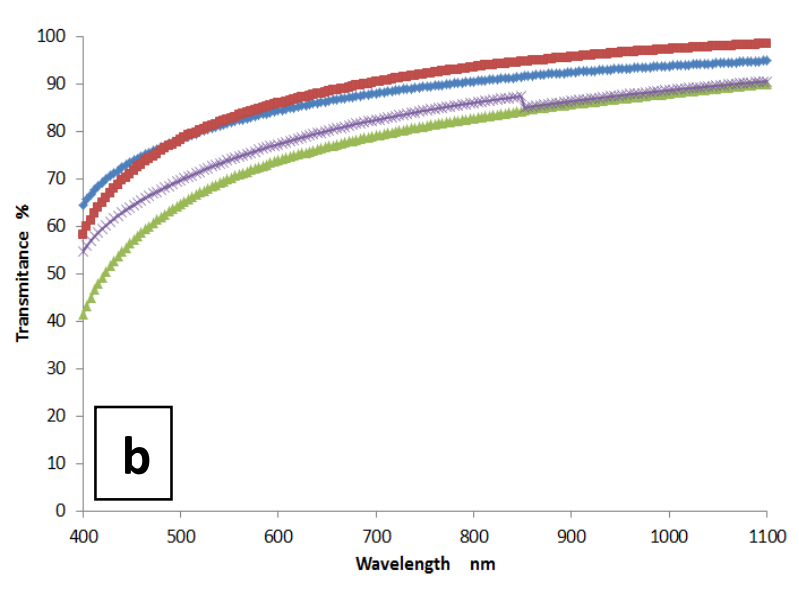

$\rightarrow-\mathrm{ZnO}$ Pure $\rightarrow-\mathrm{ZnO}: \mathrm{Cl} 4 \% \quad \rightarrow \mathrm{ZnO}: \mathrm{Br} 4 \% \quad * \mathrm{ZnOI} 4 \%$

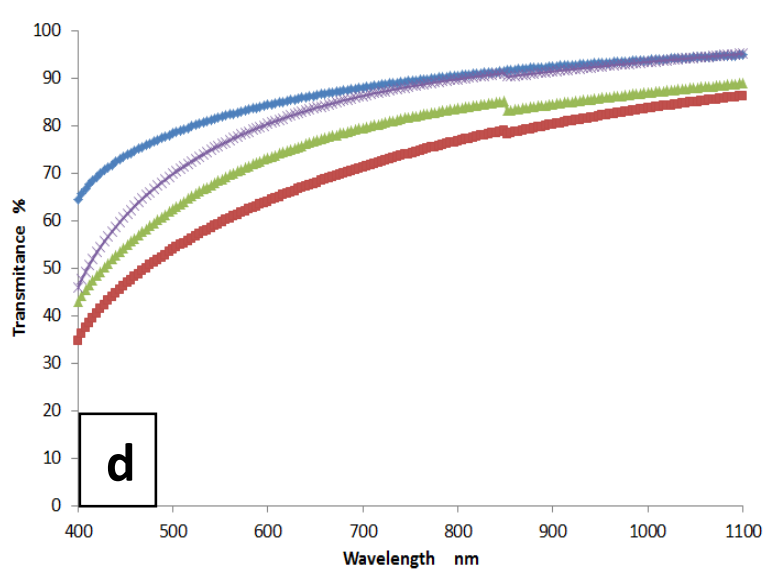

$\rightarrow$ ZnOPure $\quad-\mathrm{Z}-\mathrm{ZnO}: \mathrm{Cl} 8 \% \quad \rightarrow \mathrm{ZnO}: \mathrm{Br} 8 \% \quad \rightarrow \mathrm{ZnO}: 18 \%$

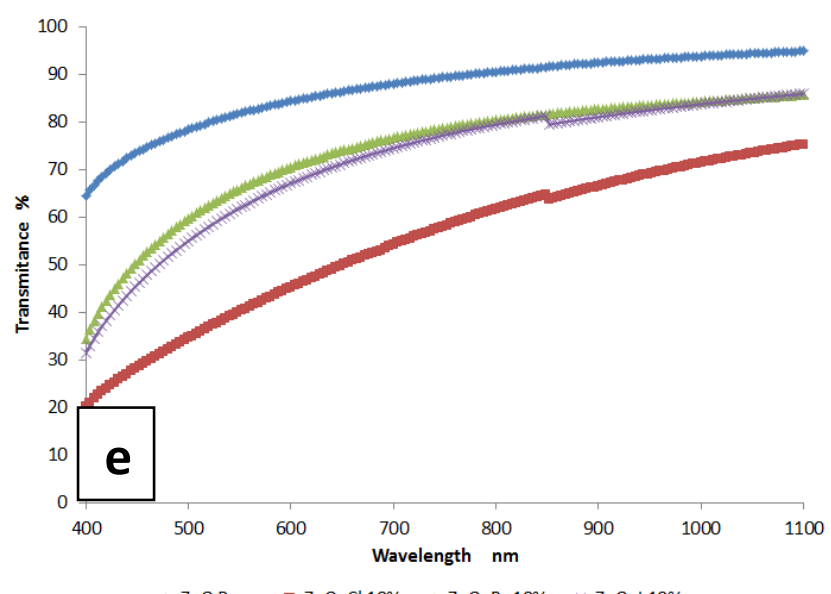

$\rightarrow-\mathrm{ZnO}$ Pure $\quad-\mathrm{ZnO}: \mathrm{Cl} 10 \% \quad \rightarrow \mathrm{ZnO}: \mathrm{Br} 10 \% \quad * \mathrm{ZnO}: 1$ 10\%

Figure 4: $\mathrm{ZnO}$ and $\mathrm{ZnO}: \mathrm{Hal}$. for 2-10\% ratios of Halogen dopants thin films transmittance spectroscopy a) $\mathrm{ZnO}: \mathrm{Hal}$ for $2 \%$, b) $\mathrm{ZnO}$ : Hal for $4 \%$, c) $\mathrm{ZnO}$ : Hal for $6 \%$ d) $\mathrm{ZnO}$ : Hal for $8 \%$ e) $\mathrm{ZnO}$ : Hal for $10 \%$

\subsubsection{Refractive indices:}

\subsubsection{Refractive index for each halogen depends on dopant ratios:}

Figure 5 displays the calculated Refractive indices of the $\mathrm{ZnO}$ pure and $\mathrm{ZnO}: \mathrm{Hal}$. films in the rage $400 \mathrm{~nm}$ to $1100 \mathrm{~nm}$ for $2-10 \%$ ratios of Halogen dopants 


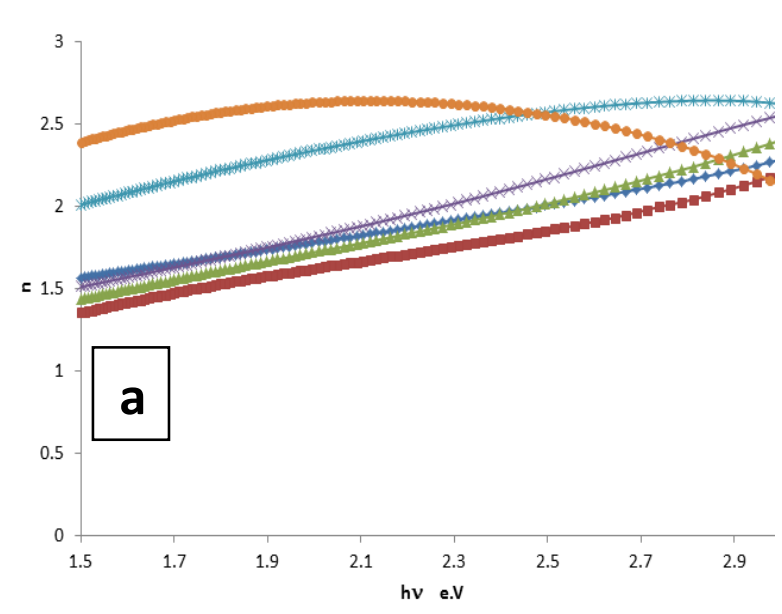

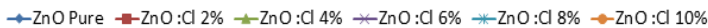

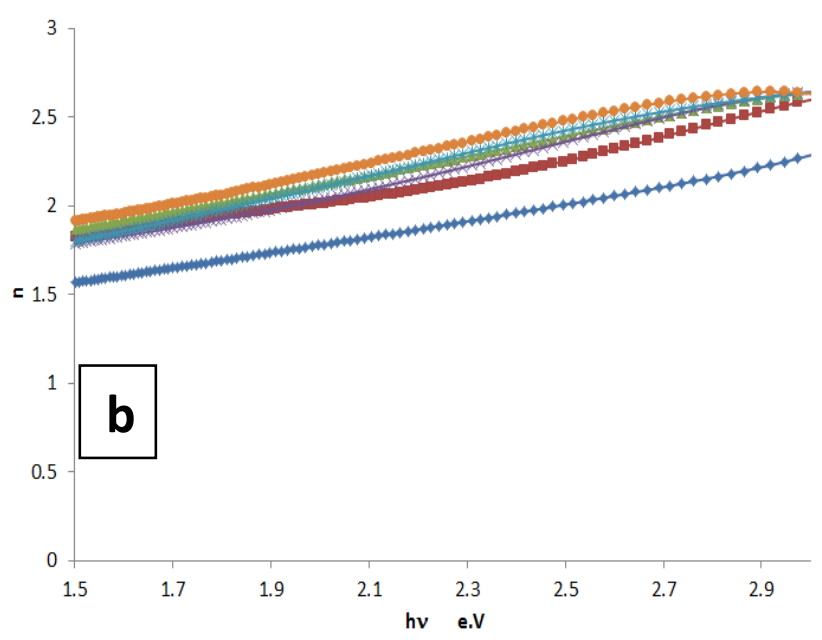

$\rightarrow-\mathrm{ZnO}$ Pure $\rightarrow-\mathrm{ZnO}: \mathrm{Br} 2 \% \rightarrow-\mathrm{ZnO}: \mathrm{Br} 4 \% * \mathrm{ZnO}: \mathrm{Br} 6 \%+\mathrm{ZnO}: \mathrm{Br} 8 \% \rightarrow-\mathrm{ZnO}: \mathrm{Br} 10 \%$

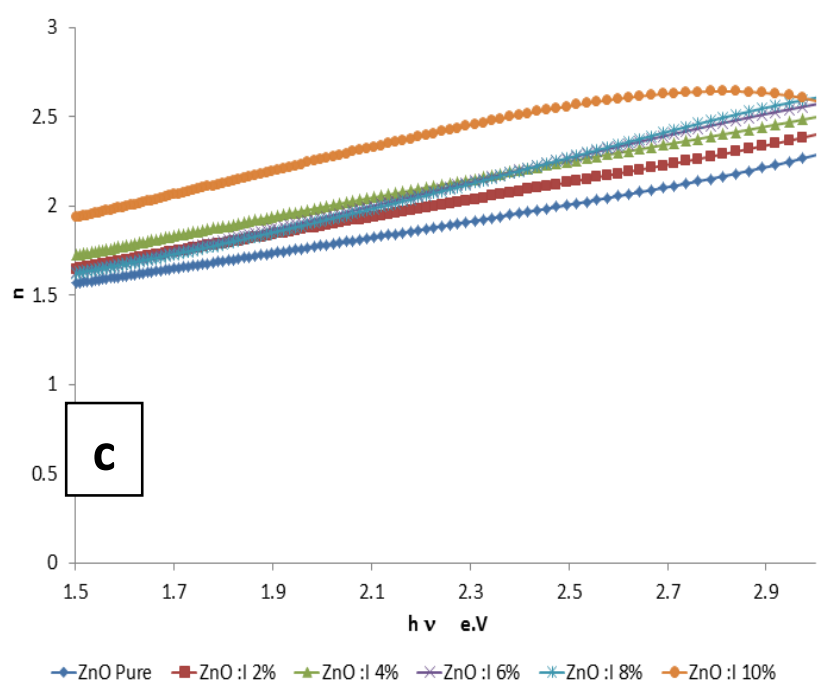

Figure 5: $\mathrm{ZnO}$ and $\mathrm{ZnO}: \mathrm{Hal}$. for 2-10\% ratios of Halogen dopants calculated Refractive index

a) $\mathrm{ZnO}: \mathrm{Cl}$ for $2-10 \%$ ratios, b) $\mathrm{ZnO}: \mathrm{Br}$ for $2-10 \%$ ratios, c) $\mathrm{ZnO}$ : I for $2-10 \%$ ratios

\subsubsection{Refractive index for halogens at fixed dopant ratios:}

Figure 6 displays the calculated refractive indices of the $\mathrm{ZnO}$ pure and $\mathrm{ZnO}: \mathrm{Hal}$. films in the rage $400 \mathrm{~nm}$ to $1100 \mathrm{~nm}$ at fixed dopant ratios from $2 \%-10 \%$

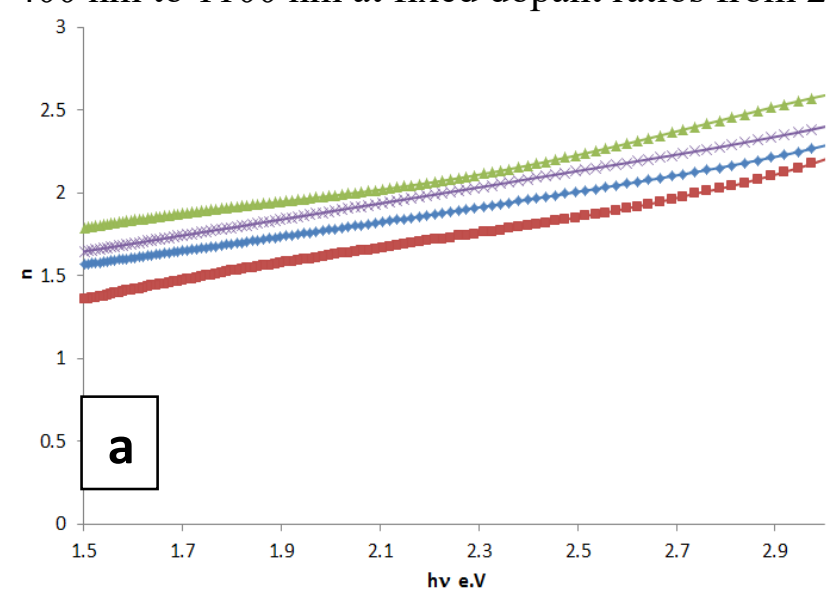

$\rightarrow-\mathrm{ZnO}$ Pure $\quad-\mathrm{ZnO}: \mathrm{Cl} 2 \% \rightarrow-\mathrm{ZnO}: \mathrm{Br} 2 \% \quad * \mathrm{ZnO}: \mathrm{I} 2 \%$

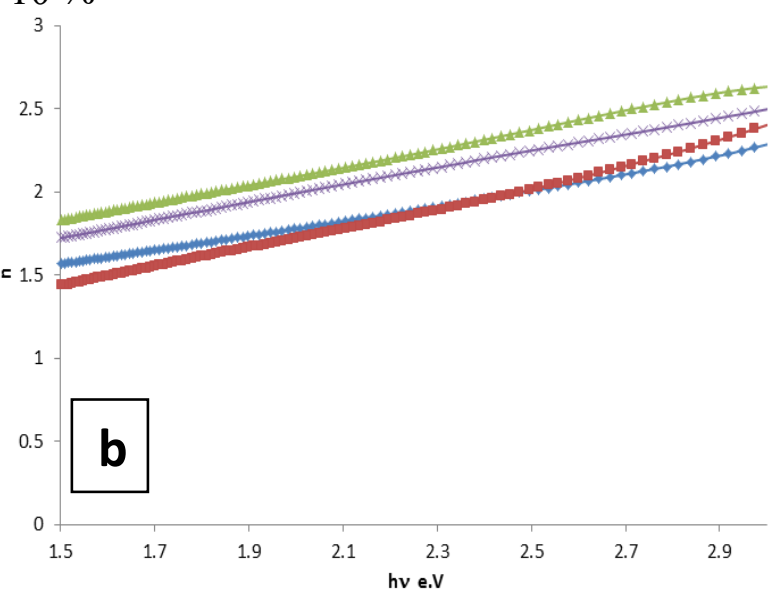

$\rightarrow-\mathrm{ZnO}$ Pure $\quad \rightarrow-\mathrm{ZnO}: \mathrm{Cl} 4 \% \quad \pitchfork \mathrm{ZnO}: \mathrm{Br} 4 \% \quad * \mathrm{ZnO}: 14 \%$ 

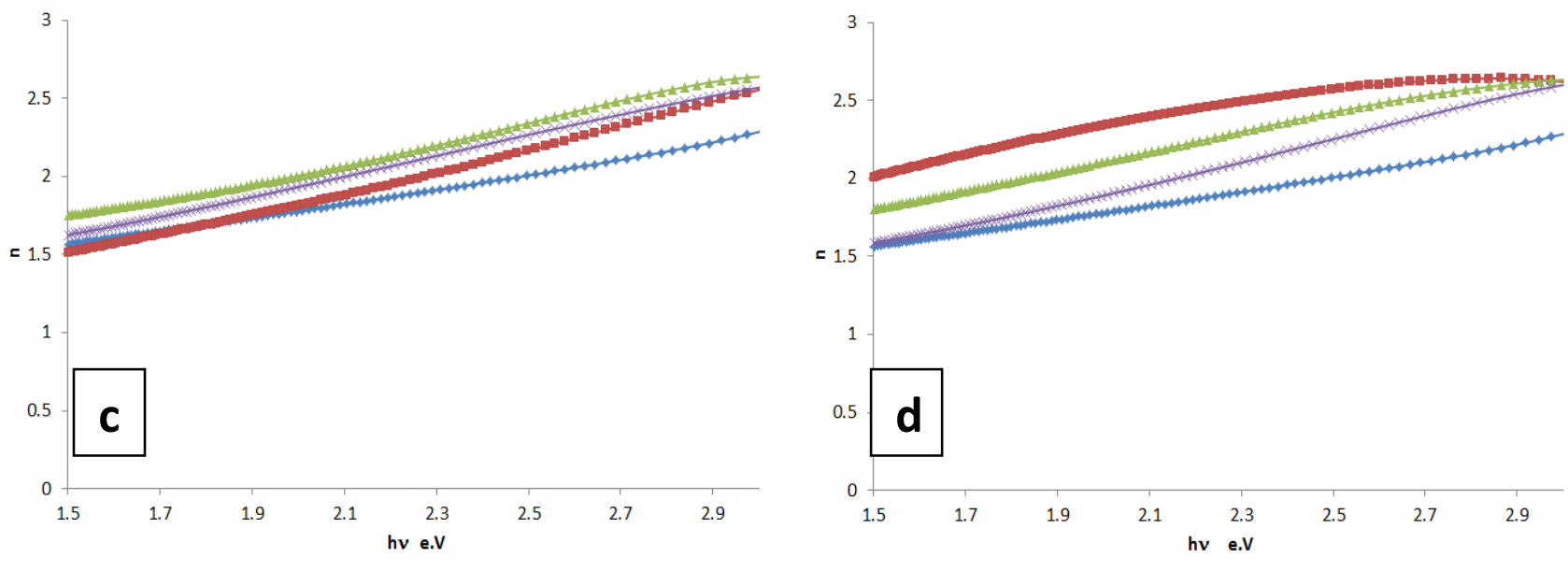

$\rightarrow-\mathrm{ZnO}$ Pure $\quad-\mathrm{m}-\mathrm{ZnO}: \mathrm{Cl} 6 \% \quad \downarrow-\mathrm{ZnO}: \mathrm{Br} 6 \% \quad \rightarrow \mathrm{ZnO}: 16 \%$

$\rightarrow-\mathrm{ZnO}$ Pure $\rightarrow-\mathrm{ZnO}: \mathrm{Cl} 8 \% \quad \rightarrow \mathrm{ZnO}: \mathrm{Br} 8 \% \quad * \mathrm{ZnO}: 18 \%$

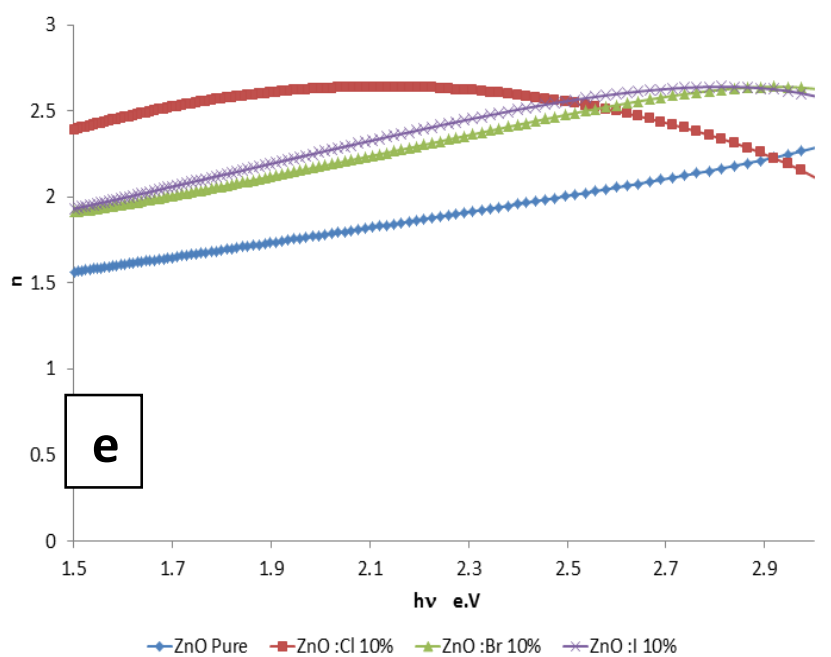

Figure 6: $\mathrm{ZnO}$ and $\mathrm{ZnO}: \mathrm{Hal}$. for 2-10\% ratios of Halogen dopants thin films transmittance spectroscopy

a) $\mathrm{ZnO}: \mathrm{Hal}$ for $2 \%$, b) $\mathrm{ZnO}$ : Hal for 4\%, c) $\mathrm{ZnO}$ : Hal for 6\% d) $\mathrm{ZnO}$ : Hal for $8 \%$ e) $\mathrm{ZnO}$ : Hal for 10\%

\subsubsection{The extinction coefficient $(k)$ :}

\subsubsection{The extinction coefficient for each halogen depends on dopant ratios:}

Figure 5 displays the calculated The extinction coefficient of the $\mathrm{ZnO}$ pure and $\mathrm{ZnO}: \mathrm{Hal}$. films in the rage $400 \mathrm{~nm}$ to $1100 \mathrm{~nm}$ for $2-10 \%$ ratios of Halogen dopants

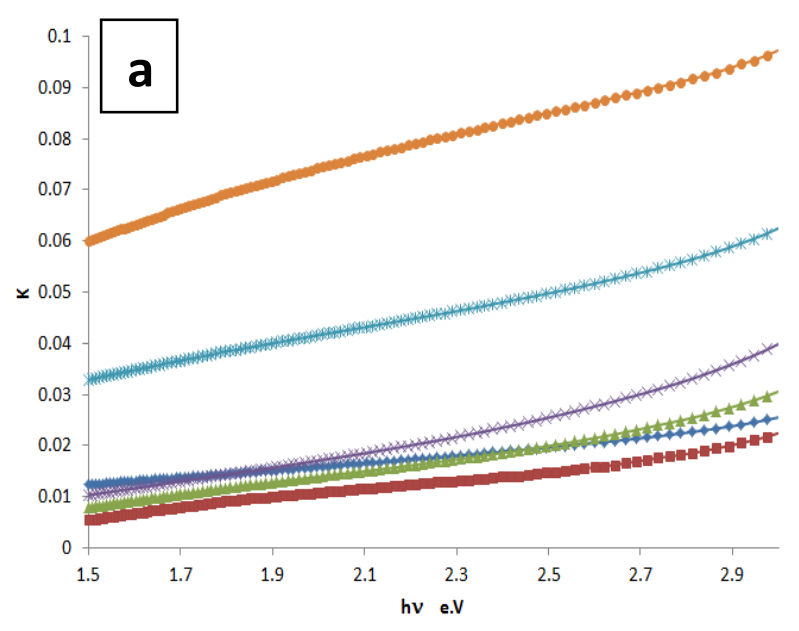

$\rightarrow$ ZnO Pure $\rightarrow-\mathrm{ZnO}: \mathrm{Cl} 2 \% \rightarrow \mathrm{ZnO}: \mathrm{Cl} 4 \% \rightarrow \mathrm{ZnO}: \mathrm{d}$ 6\% $* \mathrm{ZnO}: \mathrm{d}$ 8\% $\rightarrow-\mathrm{ZnO}: \mathrm{Cl} 10 \%$

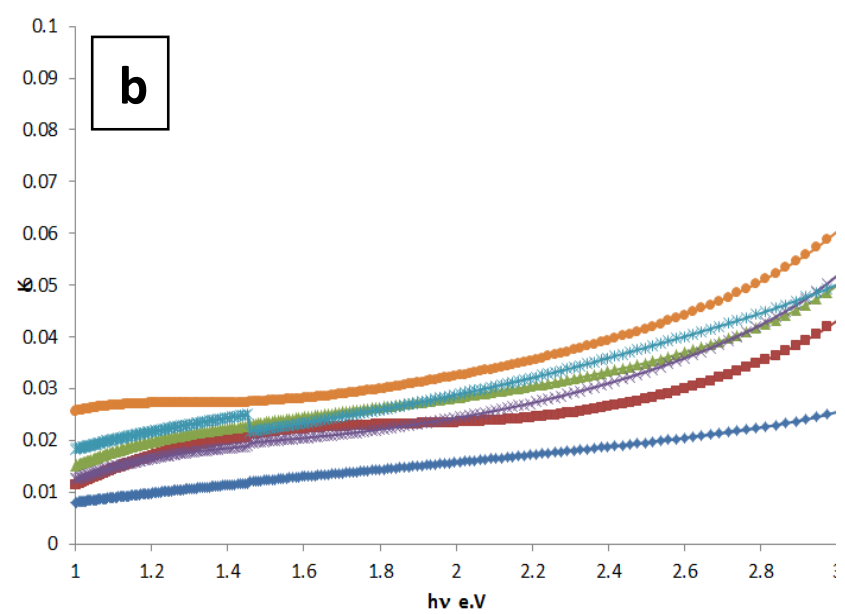

$\rightarrow-\mathrm{ZnO}$ Pure $\rightarrow-\mathrm{ZnO}: \mathrm{Br} 2 \% \rightarrow-\mathrm{ZnO}: \mathrm{Br} 4 \%+\mathrm{ZnO}: \mathrm{Br} 6 \% \rightarrow-\mathrm{ZnO}: \mathrm{Br} 8 \% \rightarrow-\mathrm{ZnO}: \mathrm{Br} 10 \%$ 


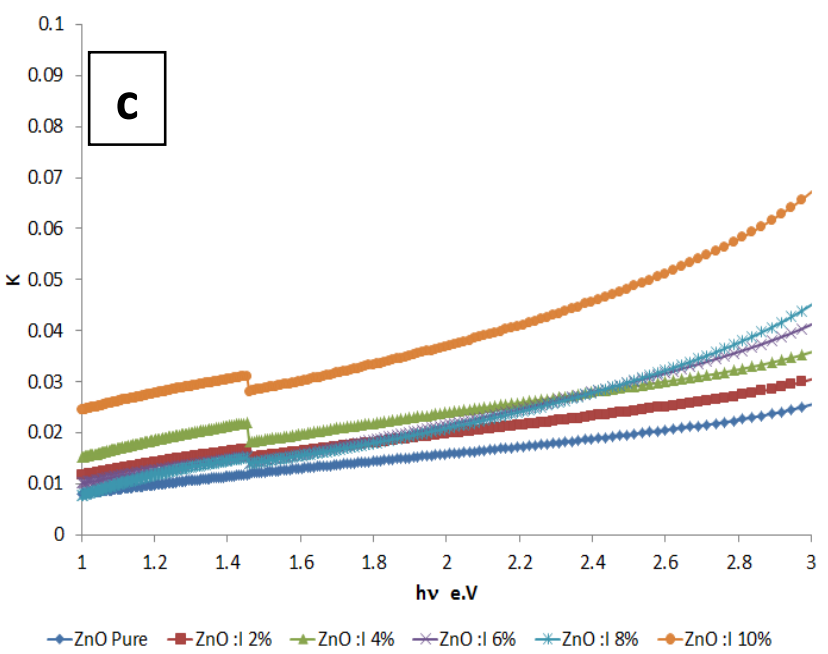

Figure 5: $\mathrm{ZnO}$ and $\mathrm{ZnO}: \mathrm{Hal}$. for 2-10\% ratios of Halogen dopants calculated the extinction coefficient a) $\mathrm{ZnO}: \mathrm{Cl}$ for $2-10 \%$ ratios, b) $\mathrm{ZnO}: \mathrm{Br}$ for $2-10 \%$ ratios, c) $\mathrm{ZnO}$ : I for $2-10 \%$ ratios

\subsubsection{The extinction coefficient for halogens at fixed dopant ratios:}

Figure 6 displays the calculated the extinction coefficient of the $\mathrm{ZnO}$ pure and $\mathrm{ZnO}$ :Hal. films in the rage $400 \mathrm{~nm}$ to $1100 \mathrm{~nm}$ at fixed dopant ratios from $2 \%-10 \%$
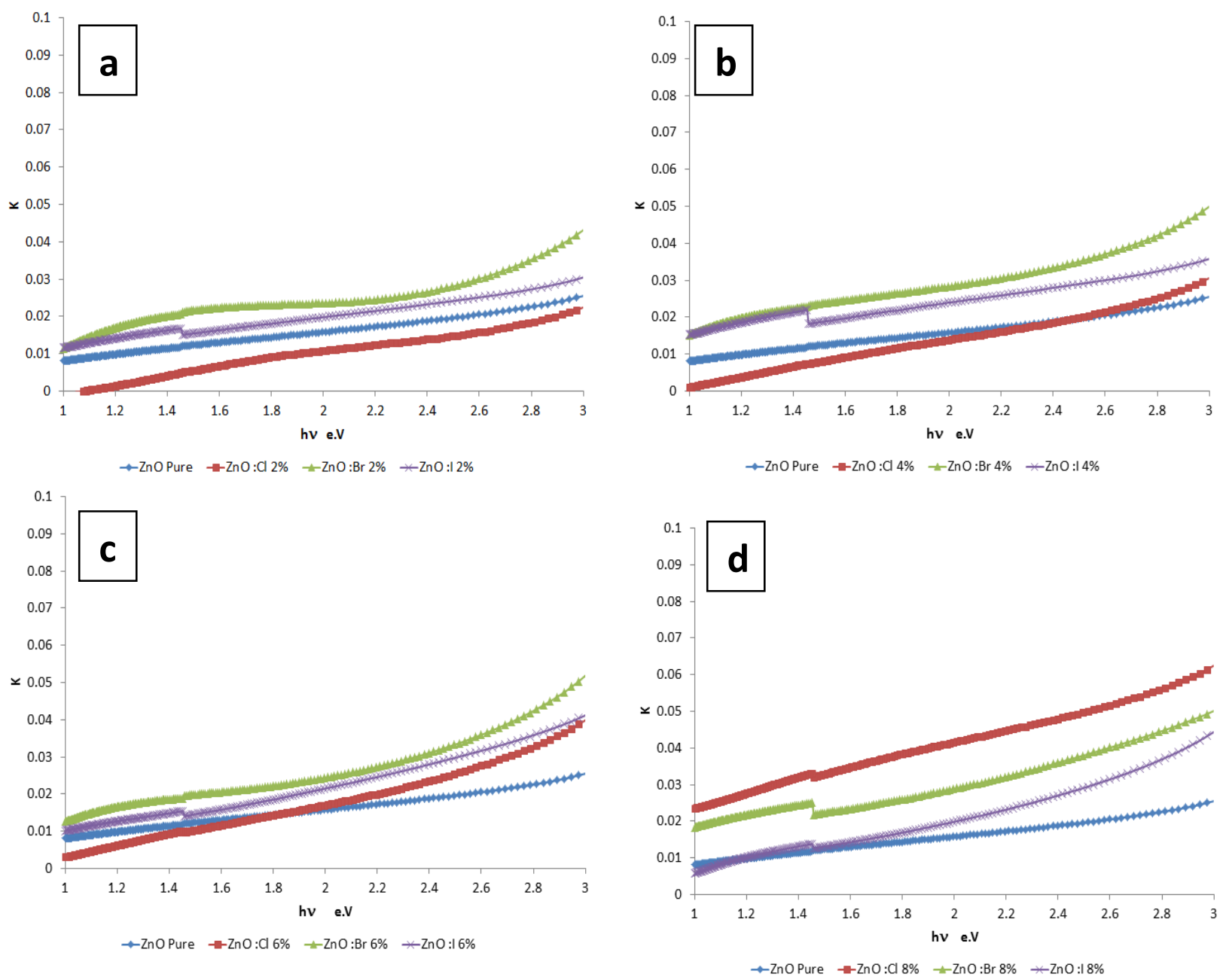


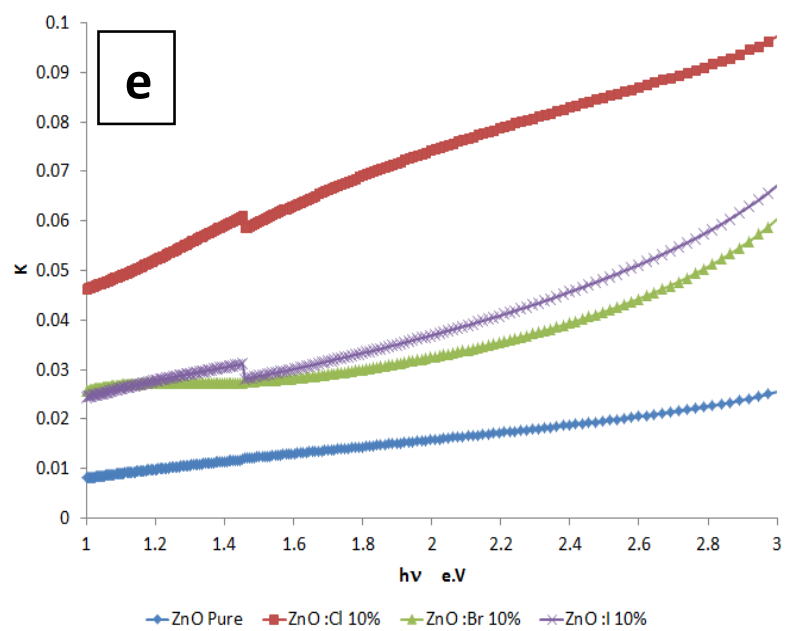

Figure 6: The extinction coefficient of $\mathrm{ZnO}$ and $\mathrm{ZnO}: \mathrm{Hal}$. for 2-10\% ratios of Halogen dopants a) $\mathrm{ZnO}: \mathrm{Hal}$ for $2 \%$, b) $\mathrm{ZnO}$ : Hal for 4\%, c) $\mathrm{ZnO}$ : Hal for 6\% d) $\mathrm{ZnO}$ : Hal for $8 \%$ e) $\mathrm{ZnO}: \mathrm{Hal}$ for $10 \%$

\subsubsection{Energy band gap}

The energy band gap could be obtained from spectroscopy measurements, and we found the following results:

\subsubsection{Energy band gap for each halogen depends on dopant ratios:}

Figure 7 displays the energy band gap of the $\mathrm{ZnO}$ pure and $\mathrm{ZnO}: \mathrm{Hal}$. films in the rage $400 \mathrm{~nm}$ to $1100 \mathrm{~nm}$ for $2-10 \%$ ratios of Halogen dopants
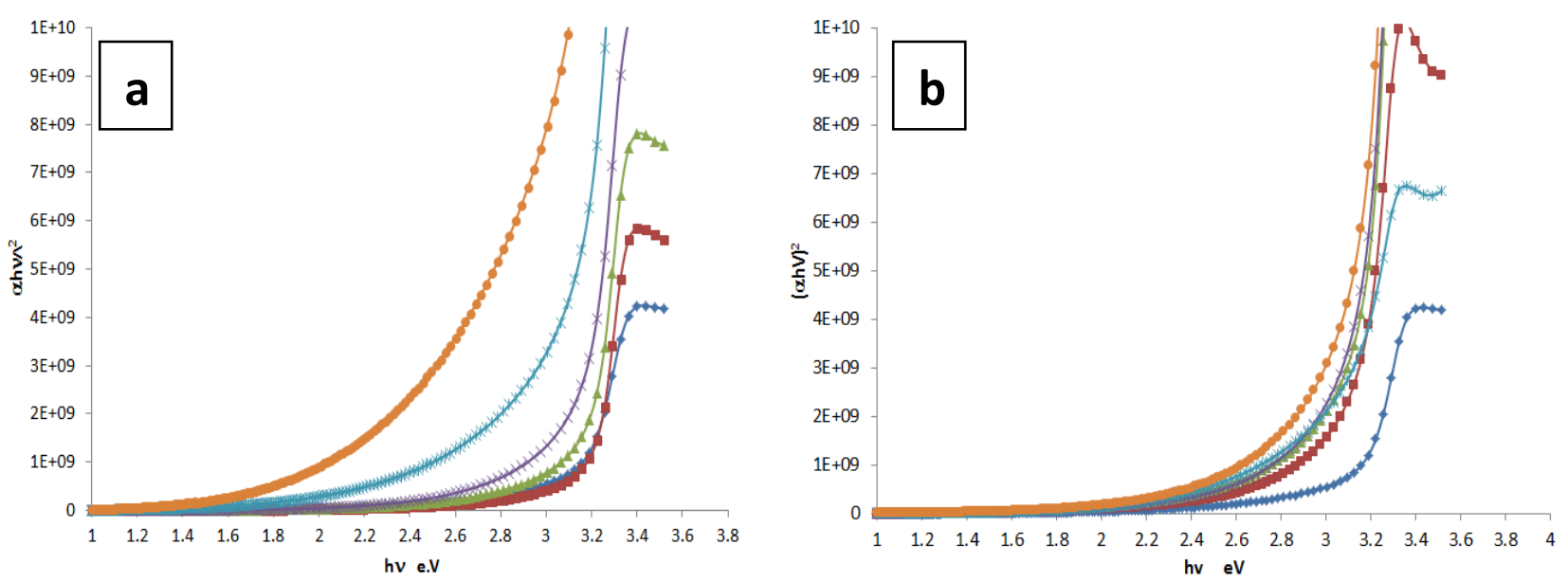

$\rightarrow-\mathrm{ZnO}$ Pure $-\mathrm{ZnO}: \mathrm{Cl} 2 \% \rightarrow-\mathrm{ZnO}: \mathrm{dl} 4 \% \rightarrow \mathrm{ZnO}: \mathrm{dl} 6 \% \rightarrow \mathrm{ZnO}: \mathrm{dl} 8 \% \rightarrow \mathrm{ZnO}: \mathrm{Cl} 10 \%$

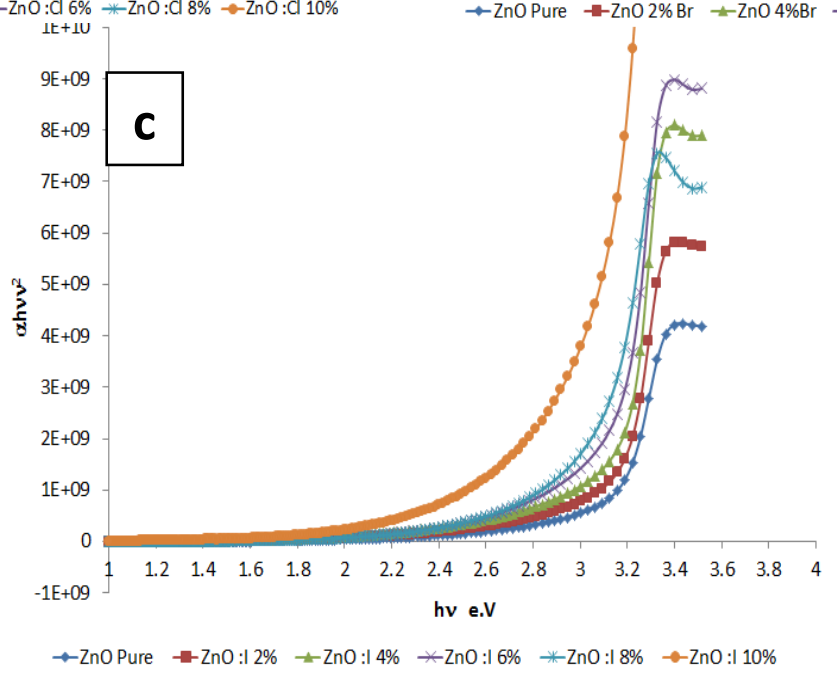

Figure 7:The energy band gap of $\mathrm{ZnO}$ and $\mathrm{ZnO}: \mathrm{Hal}$. for 2-10\% ratios of Halogen dopants

a) $\mathrm{ZnO}$ : $\mathrm{Cl}$ for $2-10 \%$ ratios, b) $\mathrm{ZnO}$ : $\mathrm{Br}$ for $2-10 \%$ ratios, c) $\mathrm{ZnO}$ : I for $2-10 \%$ ratios 


\subsubsection{Energy band gap for halogens at fixed dopant ratios:}

Figure 8 displays the energy band gap of the $\mathrm{ZnO}$ pure and $\mathrm{ZnO}: \mathrm{Hal}$. films in the rage $400 \mathrm{~nm}$ to $1100 \mathrm{~nm}$ at fixed dopant ratios from $2 \%-10 \%$ and we can summarize the whole results in table .1
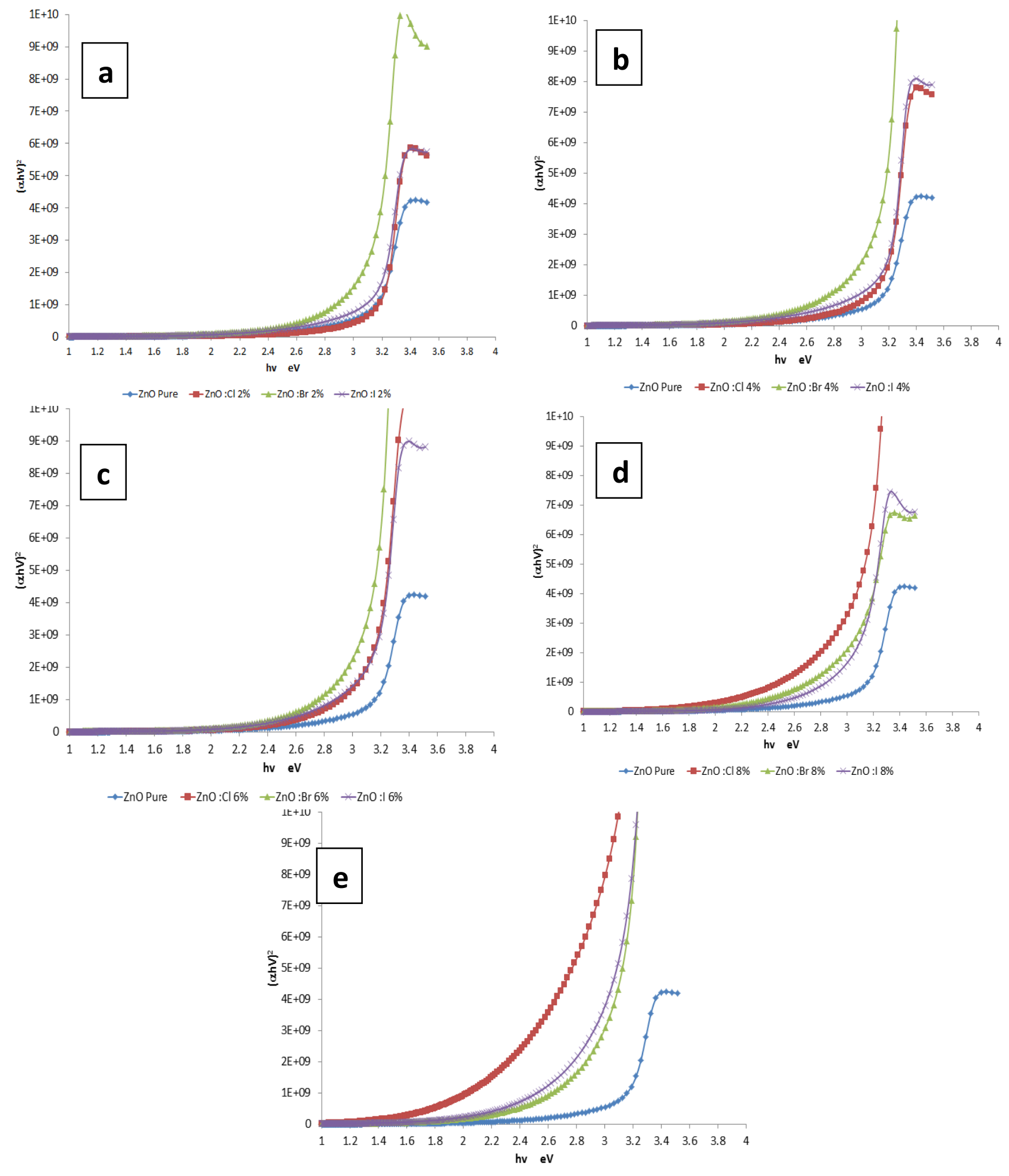

$\rightarrow$ ZnOPure $\quad-$ Zno:Cl 10\% $\rightarrow$ Zno:Br 10\% $*$ Zno:l 10\%

Figure 8: The energy band gap of $\mathrm{ZnO}$ and $\mathrm{ZnO}: \mathrm{Hal}$. for 2-10\% ratios of Halogen dopants

a) $\mathrm{ZnO}: \mathrm{Hal}$ for $2 \%$, b) $\mathrm{ZnO}$ : Hal for 4\%, c) $\mathrm{ZnO}$ : Hal for 6\% d) $\mathrm{ZnO}$ : Hal for $8 \%$ e) $\mathrm{ZnO}$ : Hal for 10\% 
Table.1 Summarize the whole results which we get from our research as follows:

\begin{tabular}{|c|c|c|c|c|c|c|c|}
\hline Sample & $\begin{array}{c}\text { Trans. } \\
\text { Range \% }\end{array}$ & $\begin{array}{l}\text { Medium } \\
\text { of trans.\% }\end{array}$ & $\begin{array}{l}\text { Refractive } \\
\text { index } \\
\text { range }\end{array}$ & $\begin{array}{l}\text { Medium of } \\
\text { refractive } \\
\text { index }\end{array}$ & $\begin{array}{c}\text { extinction } \\
\text { coefficient } \\
\text { range }\end{array}$ & $\begin{array}{l}\text { Medium of } \\
\text { extinction } \\
\text { coefficient }\end{array}$ & $\begin{array}{c}\text { Energy } \\
\text { band gap } \\
\text { e.V }\end{array}$ \\
\hline ZnO Pure & $60.0-95.1$ & 87.0 & $1.56-2.36$ & 1.84 & $0.012-0.028$ & $\mathbf{0 . 0 1 7}$ & 3.20 \\
\hline $\mathrm{ZnO}: \mathrm{Cl} 2 \%$ & 66.0-99.7 & 91.7 & $1.35-2.30$ & 1.68 & $0.005-0.025$ & 0.012 & 3.19 \\
\hline $\mathrm{ZnO}: \mathrm{Cl} 4 \%$ & $58.0-98.5$ & 88.8 & $1.44-2.46$ & 1.79 & $0.007-0.033$ & 0.015 & 3.15 \\
\hline $\mathrm{ZnO}: \mathrm{Cl6} \%$ & $49.3-97.1$ & 85.9 & $1.51-2.61$ & 1.90 & $0.010-0.045$ & 0.020 & 3.10 \\
\hline $\mathrm{ZnO}: \mathrm{Cl} \% \%$ & $34.7-86.2$ & 70.3 & $2.01-2.57$ & 2.35 & $0.030-0.067$ & 0.040 & 2.90 \\
\hline ZnO:Cl10\% & $20.1-75.3$ & 54.6 & $2.39-1.93$ & 2.50 & $0.060-0.102$ & 0.076 & 2.30 \\
\hline $\mathrm{ZnO}: \mathrm{Br} 2 \%$ & $46.2-91.7$ & 80.4 & $1.79-2.63$ & 2.06 & $0.025-0.049$ & 0.026 & 3.00 \\
\hline $\mathrm{ZnO}: \mathrm{Br} 4 \%$ & $41.3-90.1$ & 77.5 & $1.83-2.64$ & 2.15 & $0.023-0.053$ & 0.050 & 2.90 \\
\hline ZnO:Br6\% & $49.5-91.6$ & 79.6 & $1.75-2.63$ & 2.09 & $0.020-0.059$ & 0.030 & 2.90 \\
\hline ZnO:Br8\% & $42.9-88.9$ & 76.8 & $1.80-2.64$ & 2.16 & $0.022-0.054$ & 0.030 & 2.90 \\
\hline $\mathrm{ZnO}: \mathrm{Br} 10 \%$ & $34.5-85.7$ & 73.9 & $1.91-2.56$ & 2.23 & $0.027-0.067$ & 0.036 & 2.70 \\
\hline $\mathrm{ZnO}: \mathrm{I} 2 \%$ & $59.5-92.7$ & 83.8 & $1.64-2.46$ & 1.95 & $0.015-0.033$ & 0.020 & 3.10 \\
\hline $\mathrm{ZnO}: \mathrm{I} 4 \%$ & $54.6-90.6$ & 80.7 & $1.72-2.53$ & 2.04 & $0.018-0.037$ & 0.025 & 3.06 \\
\hline $\mathrm{ZnO}: \mathrm{I} 6 \%$ & $49.3-93.3$ & 82.6 & $1.63-2.62$ & 2.00 & $0.015-0.045$ & 0.024 & 3.00 \\
\hline $\mathrm{ZnO}: \mathrm{I} 8 \%$ & $45.8-95.2$ & 83.5 & $1.58-2.64$ & 1.98 & $0.013-0.049$ & 0.023 & 2.88 \\
\hline $\mathrm{ZnO}: \mathrm{I} 10 \%$ & 31.4-85.9 & 71.7 & $1.93-2.49$ & 2.29 & $0.029-0.074$ & 0.041 & 2.60 \\
\hline
\end{tabular}

From table .1 we can see that transmittance for $\mathrm{ZnO}: \mathrm{Cl} 2 \%$ is the best and near to $\mathrm{ZnO}$ pure , then the transmittance for the other goes lower with more dopant ratios, and it refers to the atom size of the dopant, but we notice the transmittance in total of $\mathrm{ZnO}: \mathrm{I}$ is better than $\mathrm{ZnO}: \mathrm{Br}$ and we think it refers to Iodide in based solution convert to $\mathrm{I}^{-}$and $\mathrm{IO}_{3}{ }^{-}$colorless which lead to more transparent thin films and get better transmittance, and for refractive index we get 1.84 , and $2.3 \mathrm{e} . \mathrm{V}$ for energy band gap that match with literature, and we get increasing with refractive index and decreasing of energy band gap with increasing of dopant ratios.

\section{CONCLUSION}

Undoped and halogen-doped zinc oxide thin films are prepared by the thermal oxidation process. Zinc acetate dehydrate, ethanol, and Diethanolamine are used as precursor, solvent, and stabilizer, respectively. In the case of $\mathrm{ZnO}$ :Hal. dopant Ammonium chloride $\mathrm{NH}_{4} \mathrm{Cl}$ 99\%, Benzene Bromide $\mathrm{C}_{6} \mathrm{H}_{5} \mathrm{Br}$, or Benzene Iodide $\mathrm{C}_{6} \mathrm{H}_{5} \mathrm{I}$ for making dopant $\mathrm{ZnO}$ thin film with $\mathrm{Cl}, \mathrm{Br}$, I respectively is added to the precursor solution with an atomic percentage equal to $2-10 . \%$ hal. The transparent solution sprayed onto glass substrates, and are transformed into $\mathrm{ZnO}$ upon annealing at $500^{\circ} \mathrm{C}$. XRD spectra of $\mathrm{ZnO}$ films show three lines $(100)$ at $2 \theta=31.77^{\circ},(002)$ at $2 \theta=34.4^{\circ}$, (101) at $2 \theta=36.25^{\circ}$ which pointed to structural characterization of $\mathrm{ZnO}$ and which disappeared directly when $\mathrm{Br}$, I was a dopant and which will decrease with increasing with $\mathrm{Cl}$ dopant ratio, and optical properties of the thin films as a function of halogen content have been investigated using U.V spectroscopy ( transmittance, refractive index, extinction coefficient and energy band gap ) for undoped and halogen-doped zinc oxide thin films were studied and found that transmittance for pure $\mathrm{ZnO}$ was $60-95.1 \%$ and go better for $\mathrm{ZnO}: \mathrm{Cl} 2 \%(66-99.7 \%)$ then it goes lower with increasing of $\mathrm{Cl}$ dopant ratio, while for $\mathrm{ZnO}: \mathrm{Br}$ was $46.2-91.7 \%$ and for $\mathrm{ZnO}: \mathrm{I}$ was 59.5-92.7\%, refractive index for pure $\mathrm{ZnO}$ was 1.84 and for $\mathrm{ZnO}: \mathrm{Cl} 2 \%$ was 1.68 , while $\mathrm{ZnO}: \mathrm{Br}$ and $\mathrm{ZnO}: \mathrm{I}$ have refractive index about $2.06,1.95$ respectively, extinction coefficient for pure $\mathrm{ZnO}$ was 0.012 0.028 and for $\mathrm{ZnO}: \mathrm{Cl} 2 \%$ was $0.0005-0.025$, while $\mathrm{ZnO}: \mathrm{Br}$ and $\mathrm{ZnO}: \mathrm{I}$ have extinction coefficient about 0.019-0.025,0.015-0.033 respectively, and for energy band gap for pure $\mathrm{ZnO}$ was $3.20 \mathrm{e} . \mathrm{V}$ and for $\mathrm{ZnO}: \mathrm{Cl} 3.19$ and goes lower with increasing of dopant ratio till $2.3 \mathrm{e} . \mathrm{V}$ for $\mathrm{ZnO}: \mathrm{Cl} 10 \%$, while $\mathrm{ZnO}: \mathrm{Br}$ and $\mathrm{ZnO}: \mathrm{I} 10 \%$ have energy band gap 2.7, $2.6 \mathrm{e} . \mathrm{V}$ respectively. 


\section{Acknowledgement}

The author expresses his thanks to Prof. Mouneer Al-HAMED, Department of Physics, Aleppo University, Faculty of Sciences, and Dr. Mouhammed KHATEEB Department of Basic sciences, Faculty of Mechanical and Electrical Engineering, University of Al-Baath, XRD and U.V Spectrophotometer laboratories at AL-BAATH University for providing all the assistance during the work.

\section{References}

[1] A. Talbi, F. Sarry, M. Elhakiki, L. Le Brizoual, O. Elmazria, P. Nicolay, P. Alnot, Sensors and Actuators A 128, 78 (2006).

[2] J. J. Chen, F. Zeng, D.M. Li, J.B. Niu, F. Pan, Thin Solid Films 485, 257 (2005).

[3] J.-B. Lee, D.-H. Cho, D.-Y. Kim, C.-K. Park, J.-S. Park, Thin Solid Films 516, 475 (2007).

[4] A. N. Banerjee, C.K. Ghosh, K.K. Chattopadhyay, H. Minoura, A.K. Sarkar, A. Akiba, A. Kamiya, T. Endo, Thin Solid Films 496, 112 (2006).

[5] J. Yoo, J. Lee, S. Kim, K. Yoon, I.J. Park, S.K. Dhungel, B. Karunagaran, D. Mangalaraj, J. Yi, Thin Solid Films 480, 213 (2005).

[6] Tseng, Y.K.; Gao, G.J.; Chien, S.C. Thin Solid Films 2010, 518, 6259-6263.

[7] Özgür, Ü.; Alivov Ya, I.; Liu, C.; Teke, A.; Reshchikov, M.A.; Doğan, S.; Avrutin, V.; Cho, S.J.; Morkoç, H. J. Appl. Phys. 2005, 98, 041301:1-041301:103.

[8] Ellmer, K.; Klein, A.; Springer Series in Materials Science; Berlin Heidelberg, Germany, 2008; Volume 104, pp. 1-33.

[9] Bundesmann, C.; Schmidt-Grund, R.; Schubert, M. Springer-Verlag: Berlin Heidelberg, Germany, 2008; Volume 104, pp. 79-124.

[10] Chen, J.L.; Chen, D.; Chen, Z.H. Sci. China Ser. E Tech. Sci. 2009, 52, 88-94.

[11] Von Wenckstern, H.; Schmidt, H.; Brandt, M.; Lajn, A.; Pickenhain, R.; Lorenz, M.; Grundmann, M.; Hofmann, D.M.; Polity, A.; Meyer, B.K. Solid State Chem. 2009, 37, 153172.

[12] Khan, F.; Singh, V.S.N.; Husain, M.; Singh, P.K. Sol. Energy.Mater. Sol. Cells 2012,100, 5760.

[13] Mueller, J.; Mahnke, M.; Schoer, G.; Wiechmann, S. AIP Conf. Proc. 2004, 709, 268-289.

[14] M. Caglar, Y. Caglar, S. Ilican, J. Optoelectron Adv. Mater. 8, 1410 (2006).

[15] F. Yakuphanoglu, Y. Caglar, S. Ilican, M. Caglar, Physica B 394, 86 (2007).

[16] Young Yi Kim, Si Woo Kang, Bo Hyun Kong, Hyung Koun Cho, Physica B 401-402, 408 (2007).

[17] L. H. Van, M.H. Hong and J. Ding, Journal of Alloys and Compounds, 449, 207 (2008).

[18] Mujdat Caglar, Saliha Ilican, Yasemin Caglar, Fahrethin Yalkuphanogh, J Mater Sci: Mater Electro, 19, 704-708 (2008).

[19] Abdullah W, International Letters of Chemistry, Physics and Astronomy Vol. 56 (2015) pp $175-183$

[20] Alhamed M. , Abdullah W. Journal of Electron Devices, Vol. 18, 2013, pp. 1563-1567

[21] Alhamed M., Abdullah W. Journal of Electron Devices, Vol. 7, 2010, pp. 246-252.

[22] Abdullah W, pH.D thesis, Aleppo University 2006. 